\title{
Ly, reis, skryf: Die Bosniese oorlog, Boeddhisme en die skryf van 'n roman
}

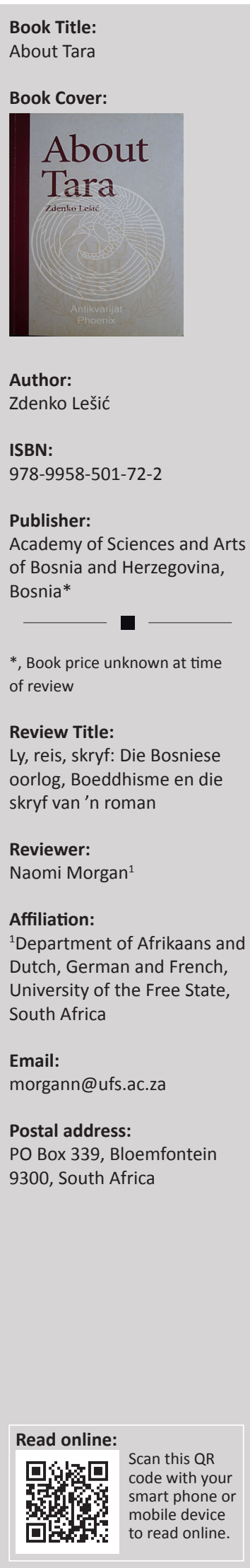

Resensente word soms gevra om 'n roman te evalueer wat buite hul verwysingsraamwerk val. Jy aanvaar die opdrag uit belangstelling in die wêreldletterkunde, of uit respek vir die opdraggewer. Soms, soos in die geval van Zdenko Lešić se About Tara, ontdek jy dan op hierdie lukrake manier een van die mees oorspronklike, roerende tekste in enige letterkunde en dank jy die kuns van vertaling wat ' $n$ onbekende Slawoniese outeur toeganklik maak vir 'n groter leserspubliek. Dit is dus nie 'n resensie oor vertaling nie omdat ek nie toegang tot die brontaal het nie; dit is 'n verslag oor 'n besondere roman.

About Tara is die Engelse vertaling deur Celia Hawkesworth van een van Lešić se twee romans (die ander is Sarajevo Tabloid). Lešić (gebore 1934) is emeritus professor in filosofie aan die Universiteit van Sarajevo, 'n bekende gasdosent in Slawoniese en Oos-Europese Studies en 'n lid van die Akademie vir Wetenskap en Kuns van Bosnië en Herzegowina, met literatuurteorie as spesialiteitsgebied. Hy het ook drie jaar in Korea gewoon, waar hy dosent was aan die Hankuk Universiteit in Seoel.

Die Tara in die titel plaas die roman in 'n Boeddhistiese konteks; die term verwys na 'n Bodhisattva of verhewe, verligte wese wat dikwels 'n karakter is in die collage van vertellings wat die roman uitmaak (soos 'n paar van die hoofstuktitels aandui: The story of Belinda, The story of the man without a name, The story of Ch'on Sang-Pyong). Deur die loop van die roman word Tara die een konstante voorbeeld van menslikheid en deernis wanneer herinneringe aan die genadelose gebeure van die Bosniese oorlog hulle aan die verteller opdring.

Dit is nie maklik om hierdie unieke roman generies te plaas nie: dit het filosofiese en sielkundige diepgang, bevat 'n sterk reiselement, verwys intertekstueel na tekste uit die Slawoniese en Oosterse literatuurtradisie (wat in 16 voetnote deur die vertaler toegelig word) en is terselfdertyd 'n roman oor die skryfproses, soos die Goncourtpryswenner François Weyergans se Trois jours chez ma mère. Lešić, wat aan die einde van 'n lang loopbaan as professor in literatuurteorie was toe hy About Tara geskryf het, toets sy teks deurlopend aan definisies van die genre sodat daar eers op bladsy 157 met die 'roman' begin word. Die rede vir soveel omsigtigheid is 'n beskeidenheid wat dikwels in traumaliteratuur gevind word, veral onder uitgeweke skrywers in 'n gasheerland (in hierdie geval Suid-Korea): trauma moet eerder verswyg word om nie aanstoot te gee nie. Die verteller verkies dit ook so omdat die herinnering aan die gewelddadige einde van vriende en familie, en veral sy twee broers, Tomislav en Josip, met tye sy geestesgesondheid bedreig. Hy sien byvoorbeeld dikwels en op onwaarskynlike plekke die geel, nommerplaatlose taxi waarin hy sy broer se stem die laaste keer gehoor het.

Hoewel dit die aanbiedingswyse is wat die leser opval, kritiseer Lešić juis implisiet daardeur die modernistiese obsessie met vorm waartoe hy voor die oorlog self as teoretikus bygedra het: 'believing, with others, that the question how? in art is far more important than the question what? And why?' (bl. 190) Die seleksie van gebeure en karakters kry hier nuwe betekenis as bron van herinnering of onverdedigbare vergetelheid:

And just as a person may be defined by what he remembers, he may also be defined by what he forgets. In the same way, a novel may be defined not only by what it evokes through its words, but also through what it does not evoke. [...] The empty spaces in it are parts of its meaning. (p. 192) [...]

As teëwig teen vergetelheid, sluit die verteller uittreksels in kursief uit Josip se oorlogsdagboek in (sien hoofstuk 13). Hierdie outobiografiese inskrywings is ook biografies, deurdat Josip besig was met 'n studie oor die digter Sterija en sy inskrywings dikwels 'n superponering van twee skrywerslewes is.

How to cite this book review: Morgan, N., 2015, 'Ly, reis, skryf: Die Bosniese oorlog, Boeddhisme en die skryf van 'n roman', Literator 36(1), Art. \#1171, 2 pages. http://dx.doi.org/10.4102/lit.v36i1.1171

Copyright: @ 2015. The Authors. Licensee: AOSIS OpenJournals. This work is licensed under the Creative Commons Attribution License. 
About Tara is 'n roman wat 'n hele loopbaan as literatuurteoretikus, en veral as narratoloog, opsom: Lešić se ervaring gedurende die Bosniese oorlog lei tot 'n jukstaposisie en selfs konfrontasie van die ontstellende inhoud van die roman en sy kennis van alle aspekte van die romanskryfproses. As sulks is die roman dus veel meer as net ' $n$ buitengewone teks; dit sou met vrug gebruik kon word as illustrasie vir toegepaste romanteorie.

Ondanks die vele teoretiese verwysings, is dit 'n hoogs leesbare, sensitiewe roman wat tot alle lesers behoort te spreek. Aspirant romanskrywers, narratoloë, lesers en navorsers wat belangstel in wêreldliteratuur, trauma-tekste en ' $n$ interessante verweefdheid van Westerse en Oosterse wêreldbeskouings sou baat vind by die lees daarvan.

Vir my as resensent is hierdie roman 'n openbaring van die tekstuele skatte wat opgesluit lê in wêrelddele en tale waarvoor daar meesal geen belangstelling aan Suid-Afrikaanse akademiese inrigtings is nie. Ironies genoeg is Lešić se soeke na sin, betekenis en vormgewing waarskynlik onontbeerlike leesstof vir Suid-Afrikaanse skrywers wat besig is met hul eie verwerking van die verlede. Enige leser wat in 'n getraumatiseerde land woon, kan identifiseer met die volgende passassie, waarin Josip die krygshere van die Bosniese oorlog tot verantwoording roep:

The other kind of murder is committed against men's souls, which you have degraded, injured, disgusted, crippled, taking from them everything that gladdened them and made them happy. That crime, the most heinous and most appalling - the murder of the soul - is what you committed [...] against many honourable and honest people, some of whom will, perhaps, get out of this hell alive, but their souls will be dead. (bl. 175) 